\title{
BCO1 Gene
}

National Cancer Institute

\section{Source}

National Cancer Institute. BCO1 Gene. NCI Thesaurus. Code C116423.

This gene is involved in the conversion of beta-carotene into retinal. 